\title{
Biochemical, Enzymatic, and Immunological Study on Antimutagenic Achillea millefolium Methanolic Extract in vivo
}

\author{
Asmaa A. Hussein, Ruqaya M. Al-Ezzy and Mays T. Abdallah \\ Biotechnology College, Al-Nahrain University, Baghdad, Iraq
}

\begin{abstract}
Traditionally medicinal plants are used for its potential chemotherapeutic action and for safety upon the continued use of these plants. Achillea millefolium (AM) is an ancient herb which is used to treat wounds, headaches, disorder in gastrointestinal and hepatobiliary, pain, and inflammation. This study was aimed to investigate the biochemical parameter of antimutagenic methanolic extract for AM in vivo. Plant extract together with MTX decreased the damage caused by the drug on the concentrations of total cholesterol and triglycerides (160.3 \pm 2.26 and $108.7 \pm 2.71)$, significant increase in total protein concentration $(8.51 \pm 0.17,9.46 \pm 0.19$ and $10.8 \pm 2.71 \mathrm{~g} \backslash \mathrm{dL}$ ) for 100 and $200 \mathrm{mg} \backslash \mathrm{kg}$ was observed. Also plant extracts counteract the damage caused by drug through the reduction for both creatinin and albumin concentrations to $1.57 \pm 0.03 \mathrm{mg} \backslash \mathrm{dL}$ and $4.56 \pm 0.09 \mathrm{~g} \backslash \mathrm{dL}$, respectively. On enzymatic level, the results of interactions indicated the ability of plant to modulating harmful effects of the drug $(57.1 \pm 1.3,130 \pm 3.1$ and $111.1 \pm 2.1 \mathrm{U} \backslash \mathrm{L})$ for GOT, GPT and ALP, respectively. On the other hand, the plant possesses the ability to enhance the concentrations of all immunoglobulin (IgM, IgA and IgG) in the two doses tested. Therefore, the results of this study indicate the antimutagenic potential of AM extract and encouraging its consumption with MTX as one of the promising therapies.
\end{abstract}

Key words: Medicinal plants, Achillea millefolium, liver function test, kidney function test, immunoglobulin.

\section{Introduction}

An important source of medicine and a large numbers of drugs were derived from plants. The therapeutic uses of plant could be due to its safe, economical and effective properties as well as their ease of availability [1].

The progressive and good result in disease treatment came from the impressive of pharmaceutical and biological activities for herbal plants [2]. On the other hand, natural and herbal medicines are believed to have many medicinal impacts as well as less adverse effects [3].

Several species of Achillea are known to use in different aspect due to their significance properties and applications in pharmaceutical, cosmetic and fragrance. Besides that, varying Achillea extracts act as

Corresponding author: Ruqaya Mohammed Ibrahim, Ph.D., lecturer, research field: biotechnology science. anti-inflammatory, antipyretic and analgesic, also this medicinal plant Achillea millefolium L. (yarrow) has shown a broad range of medical applications such as in treating the wounds, colds, fevers, stopping blood flow, kidney diseases [4].

Phytochemical studies of A. millefolium revealed that chemical constituents for this plant contain different secondary metabolites such as sesquiterpenes, essential oils, alkaloid achilleine, triterpenes, steroids, and flavonoids, as mentioned by Ref. [5]. Many of these substances showed beneficial effects in several pathological conditions, including analgesic, anti-inflammatory, antiulcer, hepatoprotective, anxiolytic, hypotensive, and antiproliferative against human tumor cells [6].

Achillea millefolium L. had the ability to protect diverse tissues against free radicals deleterious effects which resulted to cytokine activation. Also, antioxidant and hypoglycaemic properties of Achillea millefolium 
L. made it important medicinal plant. Essential oils of Achillea millefolium L. had the ability to inhibit LPS induced oxidative stress and nitric oxide production in leukaemic monocyte macrophage cell line of mouse [7].

\section{Materials and Methods}

\subsection{Plant Collection and Preparation}

The areal parts of Achillea Millefolium were supplied from the local markets and previously identified by National Herbarium of Iraq. For extract preparation [8], the dried plant material $(50 \mathrm{~g})$ was soaked with $250 \mathrm{~mL}$ of $80 \%$ ethanol, after sonication, the methanolic extract was dried by vacuum pressure, the extract was stored under sterile conditions, protected from light in a dry and cool place at $-20{ }^{\circ} \mathrm{C}$ until use.

\subsection{Experimental Design with Albino Male Mice Animals}

Albino male mice, 6-8 weeks old, body weight of 23-25 gm were purchased from Al-Nahrain University, Biotechnology Research Center Baghdad, Iraq. Four animals were housed per cage with ad libitum access to water and food pellets. They were divided into five groups: The first group was treated with $100 \mathrm{mg} / \mathrm{kg}$ of plant extract, the second group was treated with 200 $\mathrm{mg} / \mathrm{kg}$ of plant, the third group was treated with 40 $\mathrm{mg} / \mathrm{kg}$ of methotrexated drug which was the product of Pharmacia Company (Belgium), the fifth group was treated with an interaction of $40 \mathrm{mg} / \mathrm{kg}$ methotrexate and $200 \mathrm{mg} / \mathrm{kg}$ plant extract, and the last group represent the control group (normal mice without any treatment). Each investigated group was injected intraperitoneally (i.p.) with a single dose per day $(0.1$ $\mathrm{mL}$ ) of the tested material for seven days. On day 8 of the experiment, the animals were sacrificed to carry out laboratory assessments [9].

\subsection{Assessments of Biochemical, Enzymetic and Immunological Activities}

For all investigated test (biochemical, enzymetic and immunological assessments), blood was collected by heart puncture, transferred to Eppendorf tube and allowed to clot at room temperature for 15 minutes, and then serum was separated by centrifugation at 3,000 rpm for 10 minutes. That collected serum was used for the assessment of all tested parameters $[10,11]$. To carry out these assays (enzyme, biochemical and immunological activity) which determined in mouse serum by following the enzymatic colorimetric method of Ref. [10], acommercial kits (Randox Company) were used.

\subsection{Statistical Analysis}

Data in this study were presented as mean $\pm \mathrm{SD}$. The statistical programme GraphPad Prism version 5.01 (GrapgPad software, Inc., La Jolla, CA, USA), also statistical analysis system-SPSS version 14 was used. Differences between means were considered by Duncan's test, in which $P \leq 0.05$ was significant.

\section{Results}

Table 1 declared that administration of AM extract for albino male mice in groups $1(100 \mathrm{mg} / \mathrm{kg})$ and 2 (200 mg/kg) had significantly lower concentrations of total cholesterol and triglycerides to reach $163 \pm 1.82$, $152.6 \pm 1.75$ and $107.7 \pm 1.78, \quad 99.5 \pm 1.56 \mathrm{mg} \backslash \mathrm{dL}$, respectively compared to negative control. Also, administration of plant extract with MTX caused a significant reduction in total cholesterol and triglycerides $160.3 \pm 2.26$ and $108.7 \pm 2$. Regarding total protein, MTX drug caused an observed reduction in protein concentration $(4.22 \pm 0.22 \mathrm{gldL})$ in comparison with negative control $(8.15 \pm 0.19 \mathrm{~g} \backslash \mathrm{dL})$, whereas administration of plant and plant with MTX at all doses tested caused an increase in total protein concentration $(8.51 \pm 0.17,9.46 \pm 0.19$ and $10.8 \pm 2.71 \mathrm{~g} \backslash \mathrm{dL})$. Creatinin and albumin also match other results of kidney function by increasing their concentrations in mice treated with MTX $(1.78 \pm 0.03 \mathrm{mg} \backslash \mathrm{dL}$ and $7.67 \pm 0.04 \mathrm{~g} \backslash \mathrm{dL})$ respectively while AM extract showed the ability to cause reduction in a concentration in a dose dependent manner. 
Table 1 Effect of Achillea millefolium methanolic extract and MTX on biochemical parameter function in albino male mice.

\begin{tabular}{|c|c|c|c|c|c|c|}
\hline Treated groups & $\begin{array}{l}\text { Doses } \\
(\mathrm{mg} \backslash \mathrm{kg})\end{array}$ & $\begin{array}{l}\text { Total cholesterol } \\
(\mathrm{mg} \backslash \mathrm{dL}) \\
\text { Mean } \pm \text { S.E. }\end{array}$ & $\begin{array}{l}\text { Triglycerides } \\
(\mathrm{mg} \backslash \mathrm{dL}) \\
\text { Mean } \pm \text { S.E. }\end{array}$ & $\begin{array}{l}\text { Total protein } \\
(\mathrm{g} \backslash \mathrm{dl}) \\
\text { Mean } \pm \text { S.E. }\end{array}$ & $\begin{array}{l}\text { Creatinin } \\
(\mathrm{mg} \backslash \mathrm{dL}) \\
\text { Mean } \pm \text { S.E. }\end{array}$ & $\begin{array}{l}\text { Albumin } \\
(\mathrm{g} \backslash \mathrm{dL}) \\
\text { Mean } \pm \text { S.E. }\end{array}$ \\
\hline Achillea Millefolium (I) & 100 & $163.1 \pm 1.82^{\mathrm{c}}$ & $107.7 \pm 1.78^{\mathrm{b}}$ & $8.51 \pm 0.17^{\mathrm{b}}$ & $1.33 \pm 0.02^{\mathrm{c}}$ & $5.44 \pm 0.08^{b}$ \\
\hline Achillea Millefolium (II) & 200 & $152.6 \pm 1.75^{\mathrm{e}}$ & $99.5 \pm 1.56^{\mathrm{c}}$ & $9.46 \pm 0.19^{\mathrm{a}}$ & $1.20 \pm 0.02^{\mathrm{d}}$ & $6.13 \pm 0.06^{\mathrm{a}}$ \\
\hline Methotrexate Drug (III) & 40 & $202.1 \pm 1.13^{\mathrm{a}}$ & $139.5 \pm 2.96^{\mathrm{a}}$ & $4.22 \pm 0.22^{\mathrm{d}}$ & $1.78 \pm 0.03^{\mathrm{a}}$ & $3.67 \pm 0.04^{\mathrm{d}}$ \\
\hline $\begin{array}{l}\text { Achillea Millefolium+ } \\
\text { Methotrexate (IV) }\end{array}$ & $200+40$ & $160.3 \pm 2.26^{\mathrm{d}}$ & $108.7 \pm 2.71^{\mathrm{b}}$ & $6.51 \pm 0.11^{\mathrm{c}}$ & $1.57 \pm 0.03^{\mathrm{b}}$ & $4.56 \pm 0.09^{\mathrm{c}}$ \\
\hline Control group (V) & -------- & $167.4 \pm 2.97^{\mathrm{b}}$ & $105.1 \pm 1.27^{\mathrm{bc}}$ & $8.15 \pm 0.19^{b}$ & $1.47 \pm 0.02^{\mathrm{bc}}$ & $5.17 \pm 0.09^{\mathrm{b}}$ \\
\hline
\end{tabular}

Different letters: Significant difference $(P \leq 0.05)$ between means of columns.

Table 2 Liver function enzyme in albino male mice treated with Achillea millefolium extract in a comparison to MTX drug.

\begin{tabular}{lllll}
\hline Treated groups & Doses (mg $\backslash \mathrm{kg})$ & $\begin{array}{l}\text { GOT } \\
\text { Mean } \pm \text { S.E. }\end{array}$ & $\begin{array}{l}\text { GPT } \\
\text { Mean } \pm \text { S.E. }\end{array}$ & $\begin{array}{l}\text { ALP } \\
\text { Mean } \pm \text { S.E. }\end{array}$ \\
\hline Achillea Millefolium (I) & 100 & $39.3 \pm 2.3^{\mathrm{c}}$ & $92.1 \pm 1.5^{\mathrm{d}}$ & $91.6 \pm 2.03^{\mathrm{c}}$ \\
Achillea Millefolium (II) & 200 & $23.9 \pm 2.8^{\mathrm{e}}$ & $85.6 \pm 3.6^{\mathrm{e}}$ & $88.3 \pm 1.5^{\mathrm{d}}$ \\
Methotrexate drug (III) & 40 & $70.1 \pm 1.2^{\mathrm{a}}$ & $179.01 \pm 4.2^{\mathrm{a}}$ & $137.3 \pm 2.8^{\mathrm{a}}$ \\
Achillea Millefolium+ & $200+40$ & $57.1 \pm 1.3^{\mathrm{b}}$ & $130 \pm 3.1^{\mathrm{b}}$ & $111.1 \pm 2.1^{\mathrm{b}}$ \\
Methotrexate (IV) & ------- & $30.21 \pm 4.1^{\mathrm{d}}$ & $97.2 \pm 2.4^{\mathrm{c}}$ & $93.11 \pm 1.3^{\mathrm{c}}$ \\
Control group (V) & & &
\end{tabular}

Different letters: Significant difference $(P \leq 0.05)$ between means of columns.

Table 3 Comparison between the Achillea millefolium extract and MTX effects on IgM, IgA, and IgG in albino male mice.

\begin{tabular}{lllll}
\hline Treated Groups & \multirow{2}{*}{ Doses (mg $\backslash \mathrm{kg})$} & $\begin{array}{l}\text { IgM }(\mathrm{mg} \backslash \mathrm{dl}) \\
\text { Mean } \pm \text { S.E. }\end{array}$ & $\begin{array}{l}\text { IgA (mg } \backslash \mathrm{dl}) \\
\text { Mean } \pm \text { S.E. }\end{array}$ & $\begin{array}{l}\text { IgG (mg } \backslash \mathrm{dl}) \\
\text { Mean } \pm \text { S.E. }\end{array}$ \\
\hline Achillea Millefolium (I) & 100 & $96.8 \pm 5.25^{\mathrm{b}}$ & $240.8 \pm 14.6^{\mathrm{b}}$ & $1138.3 \pm 25.6^{\mathrm{b}}$ \\
Achillea Millefolium ( II) & 200 & $137.2 \pm 4.98^{\mathrm{a}}$ & $297.3 \pm 6.9^{\mathrm{a}}$ & $1379.5 \pm 38.3^{\mathrm{a}}$ \\
Methotrexate Drug (III) & 40 & $45.3 \pm 4.7^{\mathrm{d}}$ & $87.7 \pm 6.9^{\mathrm{d}}$ & $218.4 \pm 22.8^{\mathrm{e}}$ \\
Achillea Millefolium+ & $200+40$ & $70.7 \pm 4.22^{\mathrm{c}}$ & $135.1 \pm 4.47^{\mathrm{c}}$ & $645.3 \pm 50.1^{\mathrm{d}}$ \\
Methotrexate(IV) & ------ & $71.5 \pm 3.9^{\mathrm{c}}$ & $218.9 \pm 5.7^{\mathrm{b}}$ & $764.9 \pm 15.6^{\mathrm{c}}$ \\
Control Group (V) & - & & \\
\hline
\end{tabular}

Different letters: Significant difference $(P \leq 0.05)$ between means of columns.

Results for liver function enzymes (Table 2) showed the ability of AM extract to reduce the level of L.F.E. $(39.3 \pm 2.3,92.1 \pm 21.5$ and $91.6 \pm 2.03 \mathrm{U} \backslash \mathrm{L})$ for GOT, GPT and ALP at all doses in comparison with control groups. Also, interactions between Am and MTX indicated the ability of plant to modulating harmful effects of the drug $(57.1 \pm 1.3,130 \pm 3.1$ and $111.1 \pm 2.1$ $\mathrm{U} \backslash \mathrm{L})$ for GOT, GPT and ALP.

The results of immunoglobulin (IgM, IgA and $\mathrm{IgG}$ ) study (Table 3 ) indicated that mice treated with plant alone and the other treatment with plant and MTX possess the ability to enhance the concentrations of all immunoglobulin in the two doses tested (96.8 \pm 5.25 , $240.8 \pm 14.6$ and $1138.3 \pm 25.6 \mathrm{mg} \backslash \mathrm{dL}),(137.2 \pm 4.98$, $297.3 \pm 6.9$ and $1,379.5 \pm 38.3 \mathrm{mg} \backslash \mathrm{dL})$ respectively, while MTX drug reduced all immunoglobulin concentrations $(45.3 \pm 4.7,87.7 \pm 6.9$ and $218.4 \pm 22.8$ $\operatorname{mg} \backslash d L)$.

\section{Discussion}

Today the medications and nutritional supplements factories pay a special attention to natural resources, and tend to use a large amount of local flora into the production. Besides that, efforts have been gradually more to use herbal drugs as substitute medicine [9-15]. In this aspect, different recent studies have sought after to assess conventional uses and in vitro detection to identify and isolate their active compound for developing drugs from herbal origion [16, 17]. In present study we analyzed the Achillea millefolium 
effects on kidney function, liver function enzymes, and immune-enhancement activities. According to our result, methanol extract for AM had high detoxification effect against MTX drug. Also, a substantial effect which explained the ability of plant extract to interfere with the MTX and prevented its harmful effect agreed with the result of other researchers who suggested that the drug generates DNA double strand breaks through its effect on the formed topoisomerase II cleavable complex, and such effect mimics the action of ionizing radiation. A radiation-induced DNA damage has been ascribed to the production of cytokines, in particular, interleukin and its induction of release has been correlated with DNA formulation [22]. Others have suggested that the drug is activated by the oxidative effects of some enzyme, which is an abundant protein in neurophils and monocytes, and such enzyme oxidizes MTX to metabolites that can bind covalently to DNA and RNA [23]. Previous studies had shown that the active compounds found in Achillea mellifoilum species are considered as a strong anti-oxidant compound especially, the flavonoids [24-26].

In fact many species of Achillea plant exhibit a strong anti- oxidant activity, for example, the ethanolic extract of Achillea schurii had a strong anti-oxidant activity due to its ability to inhibit lipid peroxidation [27-29]. It is very important to mention that, phenolic compounds may also participate directly to antioxidant action, because of their redox properties, that permit them to act as reducing factor, hydrogen donors and singlet oxygen quenchers [30]. According to study of Ref. [31] on the phytochemical constituents of $A$. millefolium, methanolic extract of this plant contains Alkaloids (betonicine, stachydrine, trigonelline), Coumarins, Flavonoids (apigenin, luteolin, quercitin), Salicylic acid, Sesquiterpene lactones (achillin, achillicin), Polyacetylenes, Volatile oil with variable content (linalool, camphor, sabinene, chamazulene), Triterpenes, Tannins, and Sterols and plant acids [32].
Many reports improved flavonoids, phenolics and aromatics are the most important pharmacological active constituents that are powerful anti-oxidants [33]. For this reason, A. millefolium is considered a natural source of anti-oxidants, and the anti-oxidant activity of such extracts may play an important role in their anti-proliferative activities. Flavonoids can significantly cause reduction of hydrogen peroxide which means scavengers of reactive oxygen species (ROS) in humans, flavonoid concentration in plasma and most tissues is too low to effectively reduce ROS. Instead, flavonoids may play key roles as signaling molecules in mammals, through their ability to interact with a wide range of protein kinases, including mitogen-activated protein kinases (MAPK) that supersede key steps of cell growth and differentiation [34]. Such effects can be achieved through several metabolic pathways, for instances, inhibit the formation of free radicals, suppress chain initiation and/or breaking chain propagation reaction, increasing the activity of detoxifying enzymes such as glutathione transferase (GST) and superoxide dismutase (SOD) and de novo anti-oxidant and adaptation where the signal for the production and reaction of free radicals formation and transport of the anti-oxidant to the right site [35, 36].

\section{Conclusions}

In vivo assay of Achillea millefolium methanolic extract encourages its use as one of the important natural source for pharmaceutical industries and human health. The results indicated that the plant was rich in flavonoids, and such richness may have potentiated the extract to have strong anti-oxidant activities. It was also of interest to note that Achillea millefolium methanol extract exerted some immunological modulation and anti-inflammatory effects in mice. Hepatoprotective effects of the extract were overwhelmed by their potentials in reducing the hepatic damage caused by mrthotrexate drug. 


\section{References}

[1] Vishwakarma, A. P., Vishwe, A., Sahu, P., and Chaurasiya, A. 2013. "Magical Remedies of Terminalia Arjuna (ROXB)." International Journal of Pharmaceutical Archive 2: 189-201.

[2] Omidbaigi, R. 2012. Production and Processing of Medicinal Plants (6th ed.). Behnashr, AstanGhodsRazavi Press, Tehran, Iran.

[3] Bafrani, H. H., Parsa, Y., Yadollah-Damavandi, S., Jangholi, E., Ashkani-Esfahani, S., and Gharehbeglou, M. 2014. "Biochemical and Pathological Study of Hydroalcoholic Extract of Achillea millefolium L. on Ethylene Glycol-Induced Nephrolithiasis in Laboratory Rats." N Am J Med Sci. 6 (12): 638-42.

[4] Zolghadri, Y., Fazeli , M., Kooshki, M., Shomali, T., Karimaghayee, N., and Dehghani, M. 2014. "Achillea millefolium L. Hydro-Alcoholic Extract Protects Pancreatic Cells by Down Regulating IL-1 $\beta$ and iNOS Gene Expression in Diabetic Rats." Int J Mol Cell Med. 3 (4): 255-62.

[5] Al-Ezzy, R. M., Al Anee, R. S. A., and Kathum, O. A. 2017. "Hepatoprotective Effects of Achillea millefolium Methanolic Extract on Carbon Tetrachloride Induced Hepatotoxicity on Albino Male Mice." Int. J. Adv. Res. Biol. Sci. 4 (8): 98-109.

[6] Li, Y., Zhang, M. B., and Cong. B. 2011. “Achillinin A, a Cytotoxic Guaianolide from the Flower of Yarrow, Achillea millefolium." Bioscience, Biotechnology and Biochemistry 75 (8): 1554-6.

[7] Chou, S.-T., Peng, H.-Y., and Hsu, J.-C. 2013. "Achillea millefolium L. Essential Oil Inhibits LPS-induced Oxidative Stress and Nitric Oxide Production in RAW 264.7 Macrophages.” Int J Mol Sci 14: 12978-93.

[8] Taskeen, A., Naeem, I., Mubeen, H., and Mehmood, T. 2009. "Reverse Phase High Performance Liquid Chromatographic Analysis of Flavonoids in Two Ficus Species." New York Sci. J. 2: 32-5.

[9] Al-Ezzy, R. M., Mohammed Hassan, Z. Y., and Al-Jumaili, F. T. O. 2017. "Hematological Toxic Effect and the Frequency of Micronucleus Formation of Different Doses of Cyproheptadine on Albino Male Mice Blood Picture.” Iraqi Journal of Hematology 37: 149-53.

[10] Reitman, S., and Frankel, S. 1957. "A Colorimetric Method for the Determination of Serum Glutamic Oxalacetic and Glutamic Pyruvic Transaminases." Am J Clin Pathol. 28: 56-63.

[11] Varan, G., Öncül, S., Ercan, A., Benito, J. M., Mellet, C. O., and Bilensoy, E. 2016. "Cholesterol-Targeted Anticancer and Apoptotic Effects of Anionic and Polycationic Amphiphilic Cyclodextrin Nanoparticles." Journal of Pharmaceutical Sciences 105 (10): 3172-82.
[12] Yuan, H. D., Ma, Q. Q., Ye, L., and Piao, G. C. 2016. "The Traditional Medicine and Modern Medicine from Natural Products." Molecules 21: 559.

[13] Sarrafchi, A., Bahmani, M., Shirzad, H., and Rafieian-Kopaei, M. 2015. "Oxidative Stress and Parkinson's Disease: New Hopes in Treatment with Herbal Antioxidants." Curr Pharm Des. 22 (2): 238-46.

[14] Samarghandian, S., Asadi-Samani, M., Farkhondeh, T., and Bahmani, M. 2016. "Assessment the Effect of Saffron Ethanolic Extract (Crocus sativus L.) on Oxidative Damages in Aged Male Rat Liver.” Der Pharm Lett. 8 (3): 283-90.

[15] Moradi, M. T., Karimi, A., and Alidadi, S. 2016. "In vitro Antiproliferative and Apoptosis-Inducing Activities of Crude Ethyle Alcohole Extract of Quercus brantii L. Acorn and Subsequent Fractions." Chin J Nat Med. 14 (3): 196-202. doi: 10.1016/S1875-5364.

[16] Karimi, A., and Moradi, M. T. 2015. "Total Phenolic Compounds and in vitro Antioxidant Potential of Crude Methanol Extract and the Correspond Fractions of Quercus brantii L. Acorn.” J Herbmed Pharmacol. 4 (1): 35-9.

[17] Yousefi, B., Abasi, M., Abbasi, M. M., and Jahanban-Esfahlan, R. 2015. "Anti-proliferative Properties of Cornus Mass Fruit in Different Human Cancer Cells." Asian Pac J Cancer Prev. 16 (14): 5727-31.

[18] Bahmani, M., Mirhoseini, M., Shirzad, H., Sedighi, M., Shahinfard, N., and Rafieian-Kopaei, M. 2015. "A Review on Promising Natural Agents Effective on Hyperlipidemia." J Evid Based Complementary Altern Med. 20 (3): 228-38. doi:10.1177/2156587214568457.

[19] Moradi, M. T., Karimi, A., Alidadi, S., and Gholami-Arjenaki, M. 2015. "In vitro Anti-herpes Simplex Type-1 Activity, Antioxidant Potential and Total Phenolic Compounds of Pomegranate (Punica granatum L.) Peel Extract." J Chem Pharm Res. 7 (8): 82-8.

[20] Naghdi, N., Asadi-Samani, M., and Rafieian-Kopaei, M. 2016. "The Most Important Medicinal Plants Effective on Constipation by the Ethnobotanical Documents in Iran: A Review.” Der Pharm Lett. 8 (2): 188-94.

[21] Sani, M. R. M., Asadi-Samani, M., Rouhi-Boroujeni, H., and Banitalebi-Dehkordi, M. 2016. "Phytopharmacology and Phytotherapy of Regulatory T Cells: A New Approach to Treat Multiple Sclerosis." Der Pharm Lett. 8 (3): 215-20.

[22] Ponnappa, B. C., Israel, Y., Aini, M., Zhou, F., Russ, R., Cao, Q. N., Hu, Y., and Rubin, R. 2005. "Inhibition of Tumor Necrosis Factor Secretion and Prevention of Liver Injury in Ethanol-Fed Rats by Antisense Oligonucleotides.” Biochem Pharmacol 69 (4): 569-77.

[23] Tsimokha, A., Kulichkova, V., Karpova, E., Zaykova, J., Aksenov, N., Vasilishina, A., Kropotov, A., Antonov, A., 
and Barlev, N. 2014. "DNA Damage Modulates Interactions between Micro-RNAs and the 26S Proteasome.” Oncotarget 5: 3555.

[24] Popovici, M., Vlase, L., Oniga, I., and Tamas, M. 2007. "HPLC Analyses on Polyphenolic Compounds from Achillea Species.” FARMACIA-BUCURESTI 55 (3): 353.

[25] Al-Ezzy, R. M., Al Anee, R. S. A., and Ibrahim, N. A. 2018. "Assessments of Immunological Activity of Achillea Millefolium Methanolic Extract on Albino Male Mice.” Journal of Pharmacy and Pharmacology 6: 563-9.

[26] Serdar, G., Sökme, M., Demir, E., Sökmen, A., and Bektas, E. 2015. "Extraction of Antioxidative Principles of Achilleabiserrata M. Bieb and Chromatographic Analyses.” Int J. Second. Metab 2: 3-15.

[27] Prior, R. L., Wu, X., and Schaich, K. 2005. "Standardized Methods for the Determination of Antioxidant Capacity and Phenolics in Foods and Dietary Supplements." $J$. Agric. Food Chem 53: 4290-302.

[28] Vlase, L., Benedec, D., Hanganu, D., Damian, G., Csillag, I., Sevastre, B., Mot, A. C., Silaghi-Dumitrescu, R., and Tilea, I. 2014. "Evaluation of Antioxidant and Antimicrobial Activities and Phenolic Profile for Hyssopus officinalis, Ocimum basilicum and Teucrium chamaedrys.” Molecules 19: 5490-5507.

[29] Benedec, D., Oniga, I., Muresan, B., Mot, A. C., Damian, G., Nistor, A., Silaghi-Dumitrescu, R., Hanganu, D., Duma, M., and Vlase, L. 2014. "Contrast between Waterand Ethanol-based Antioxidant Assays: Aspen (Populustremula) and Black Poplar (Populusnigra) Extracts as a Case Study.” J. Food Qual. 37: 259-67.

[30] Rezende, T. P., Corrêa, J. O. A., Aarestrup, B. J. V.,
Aarestrup, F. M., de Sousa, O. V., and Filho, A. A. S. 2014. "Protective Effects of Baccharis dracunculifolia Leaves Extract against Carbon Tetrachloride- and Acetaminophen-induced Hepatotoxicity in Experimental Animals.” Molecules 19: 9257-72.

[31] Kim, H., Choi, H., Moon, J., Kim, Y., Mosaddik, A., and Cho, S. 2011. "Comparative Antioxidant and their Correlation with Flavonoid and Polyphenol Content.” Journal of Food Science 76 (1): 38-48.

[32] Shamsee, Z. R., Al-Saffar, A. Z., Al-Shanon, A. F., and Al-Obaidi, J. R. 2018. Cytotoxic and Cell Cycle Arrest Induction of Pentacyclic Triterpenoids Separated from Lantana Camara Leaves against MCF-7cell Line in vitro. Molecular biology reports.

[33] Al-Saffar, A. Z., Al-Shanon, A. F., Al-Brazanchi, S. L., Sabry, F. A., Hassan, F., and Hadi, N. A. 2017. "Phytochemical Analysis, Antioxidant and Cytotoxic Potentials of Pelargonium Graveolens Extract in Human Breast Adenocarcinoma (MCF-7) Cell Line.” Asian Journal of Biochemistry 12: 16-26.

[34] Galleano, M., Verstraeten, S., Oteiza, P., and Fraga, C. 2010. "Review Antioxidant Actions of Flavonoids: Thermodynamic and Kinetic Analysis.” Arch. Biochem Biophys. 1501 (1): 23-30.

[35] Narange, A., Jha, P., Rawat, V., Mukhopdh, A., and Dash, D. 2011. "Recent Admixture in an Indian Population of African Ancestry.” Am J Hum Genet. 89 (1): 111-20.

[36] Ibrahim, R. M. 2018. "Effect of Aqueous Extract of Rosemary officinalis on Cytotoxicity of CCL4 Induced Albino Male Mice.” Journal of Biotechnology Research Center 12 (1): 124-31. 